\title{
IS VERTICAL SEPARATION A PREREPUISITE TO ENHANCING COMPETITION IN THE SOUTH AfRICAN ENERGY INDUSTRY?
}

\author{
Thembalethu Sithebe ${ }^{*}$ \\ Competition Commission of South Africa \\ thembalethu.sithebe@gmail.com
}

Received: June 2014

\author{
Tshekishi Kolobe+ \\ Genesis Analytics \\ tshekishik@geneis-analytics.com
}

Accepted: September 2014

\begin{abstract}
Vertical separation is believed to have positive effects in energy sectors where certain phases of the value chain operate under a natural monopoly. This paper discusses whether unbundling is necessary in the South African electricity and piped gas sectors to encourage entry and increase competition based on the experiences of other nations. Despite positive results in some instances, unbundling does not always result in higher levels of competition and benefits for consumers. In fact, in some cases, vertical separation has resulted in energy sectors that are worse off.
\end{abstract}

Keywords

Vertical integration, electric utilities, electricity markets gas utilities, gas, vertical separation

*Ms T Sithebe is a senior economist at the Competition Commission of South Africa

\#MrT Kolobe is an analyst at Genesis Analytics, South Africa 


\section{THE \&CONOMICS OF UNBUNDLING}

The liberalisation of the energy sector globally was conceived with the idea of benefitting industry and consumers through lower energy prices and ensuring security of supply. Achievement of these benefits relies on the creation of efficient and competitive markets which can offer high quality and varied services at lower prices to energy users. It is generally believed that for markets to evolve and function effectively new market entry should be possible and there should be a sufficient number of participants who are able to compete with each other.

The neoclassical model of perfect competition relies on the assumption of free and costless entry and exit from a market. This means that in a frictionless market, when demand for the product increases a higher market clearing price will result. This higher price acts as a signal to producers operating in the market to increase their production. The additional quantity produced will be sold at a higher margin, allowing for the producers to earn additional revenue in excess of cost. The higher margin and resulting additional revenues act as a signal to potential entrants, indicating that entry into this market is profitable.

This reasoning is dependent on market entry being frictionless and costless. If the market were to have some barrier to entry that adversely influences the profitability of entry (such as the existence of sunk costs, economies of scale or any other cost advantage that makes entry unprofitable), the market-clearing price would no longer serve as a signal indicating the profitability of a market. In this case, the potential entrant would observe a high price in the market but would not enter if entry is costly. Notably, two features remain in the market: (a) the high price charged to consumers and (b) the excess market demand. Thus, the existence of entry barriers impede the ability for the market to clear, and competition may be limited.

This is particularly true in the energy industry, which possesses unique characteristics that make entry difficult. The energy industry may be described as a network industry. Soares and Sarmento (2010:4) define a network industry as an industry with significant economies of scope or scale, and a large degree of vertical and horizontal integration. These are industries that often have a production chain that involves separate activities which provide complementary services used in the production of the final good. There are certain stages in the production chain that cannot viably be duplicated (due to high sunk costs), and thus allowing a single firm to operate in the market ensures low-cost provision of the final good. Consequently, entry in these markets is not frictionless, and even if entry does occur a competitive market outcome may not eventuate.

Vertical separation is thought to be the most efficient way to encourage market entry in network industries (European Federation of Energy Traders, 2000:2). Vertical separation is the structural solution proposed to separate activities that are amenable to competition from those that are not (European Federation of Energy Traders, 2000:2). Numerous arguments in favour of vertical separation have been advanced, the two main ones being that (1) the network operator will have less of an incentive to discriminate between the affiliated and independent generators; and (2) the network operator will have an incentive to invest in transmission capacities (Haucap, 2007:302). Another important argument favouring vertical separation is related to the reduction of regulatory intervention through the development of competition (Soares \& Sarmento, 2010:5).

Vertical integration is also associated with efficiencies. Michaels (2004:4) stated that vertical integration is an efficient organisation choice if (i) assets are highly specific to a given use or location, and (ii) they are utilised in activities that must be coordinated. This is particularly 
relevant for network industries such as the energy industry, where retaining ownership of the activities to a single entity may allow for greater synergies and consequently an increase in scale and lower-cost production. However, it is generally thought that vertical integration increases entry barriers and that this may be used by the integrated entity against potential competitors (Soares \& Sarmento, 2010:15). Thus, the basic assumption behind calls for vertical separation is that by opening up the market, competition will increase as the barriers to entry are reduced. It is noted that this line of thinking oversimplifies the reform process for network industries. The separation of potentially competitive activities from network activities is just one step in the reform process towards the development of competitive markets. This paper will analyse this simple reading of economics by considering the experience of various countries with the separation of vertical relationships in the electricity and piped gas industries and infer policy implications for South Africa.

Section 2 provides an outline of the South Africa electricity sector, including its structure, and questions whether vertical separation is appropriate given the status of the electricity supply industry. Section 3 discusses the South African piped gas sector and poses the same question regarding calls for vertical separation of the sector. In section 4 , the experiences of unbundling in other countries are discussed. Finally, section 5 develops the policy implications of unbundling in the electricity and natural gas sectors in the South African context. The main lesson drawn from this study is that vertical separation does not in itself lead to effective competition and increased entry. Instead, a cautionary approach should be used (which takes account of other market conditions that facilitate competition) when restructuring the regulated energy industries.

\section{SOUTH AFRICA'S \&LECTRICITY SECTOR}

Electricity provision has always been thought of as a natural monopoly (Hertzmark, 2012:2). This is due to the high investment costs as well as an understanding of significant economies of scale that exist in the industry. The generation and supply of electricity has usually occurred through vertically integrated systems. The key stages of the electricity value chain - generation, transmission and distribution - are usually owned and operated by one entity. Until 1990, this meant that the provision of electricity was the domain of state-owned utilities in most countries aside from the United States of America and a few others (Hertzmark, 2012:3). Indeed, this remains the case in South Africa (with Eskom).

\subsection{Structure of the electricity sector}

Eskom is a state-owned utility generating two-thirds of Africa's electricity and at least $95 \%$ of South Africa's electricity (Mali, 2013). It generates electricity from mainly coal-based sources, owns and operates the high voltage transmission grid that covers the country and distributes electricity together with municipalities. Energy-intensive users such as the mining houses purchase electricity directly from Eskom, while residential and commercial customers' access electricity mainly through the municipalities, which act as distribution agents (Steyn, 2003:1). 


\section{Electricity Generation}

Electricity generation is the production of electricity using renewable and non-renewable raw materials such as coal. In South Africa, $95 \%$ of electricity is generated by Eskom, with the remainder provided by independent power producers (IPPS) as well as renewable sources from SADC countries (Eskom report, 2012). There have been key challenges in maintaining the generation capacity of electricity in South Africa. These challenges have been assessed by Steyn (2003), who notes that the inherent trade-off between providing electricity at a low price and ensuring all costs are covered and sufficient returns are made on investments in the sector is considered one of the key issues in electricity generation in South Africa.

\section{Electricity Transmission}

Transmission infrastructure is owned and operated by Eskom. Similar to electricity generation, this level of the value chain has suffered from underinvestment, resulting in a maintenance backlog (National Treasury, 2013).

\section{Electricity Distribution}

Currently Eskom distributes electricity to key industrial users, which account for $55 \%$ of the electricity consumed. The remainder is sold by Eskom to municipalities, who then act as retailers for residential customers and the rest of the commercial sector.

\subsection{Electricity supply industry policy context}

\section{Entry into the South African electricity supply industry}

International experience indicates that the generation of electricity does not exhibit natural monopoly tendencies, while the transmission and distribution segments do. This is due to the competitive nature of the electricity generation stage where alternative energy sources are available. However, the competitive nature of the generation stage is dependent on the minimum efficient scale of the generating plants relative to the market demand for electricity. Generation also does not require the large investments in infrastructure associated with other functions such as transmission. Consequently, energy regulators have advocated greater competition in the generation segment. Recently, however, the delineation of natural monopoly boundaries has shifted significantly as upstream (i.e. generation segment) and downstream (i.e. retail segment) competition has been introduced. Thus, the natural monopoly portion of the value chain refers more to the transmission grid or systems network only. This rethinking of the natural monopoly boundaries has allowed for the introduction of independent power producers (IPPs), in most countries, in the generation segment (Hertzmark, 2012:9).

However, problems with capacity underinvestment in the South African ESI sector still remain. This is regardless of government initiatives to facilitate entry. This leads one to question whether the separation of the vertically integrated entity is a necessary prerequisite to facilitate entry into the South African electricity generation segment. Numerous policy initiatives have been proposed to encourage greater competition in the market in South Africa.

These policy initiatives date as far back as 1998, when the White Paper on the Energy Policy of the Republic of South Africa was released. The initiatives sought to address the issues surrounding entry into the market and capacity. The policy initiatives considered various issues, and in fact some appear repeatedly. Common themes included: 
(i) The encouragement of entry and competition, especially in the generation market.

(ii) Ensuring security of supply, one of the ways being through a diverse energy mix.

(iii) The restructuring of Eskom into separate generation and transmission entities.

(iv) The introduction of an independent systems operator (ISO), which would provide nondiscriminatory access to the transmission system.

(v) Power purchase agreements that would ensure that the electricity generated by IPPs would indeed be bought.

The table below summarises the main policy documents and the main ideas put forward in these documents in relation to the problems facing the electricity supply industry in South Africa.

\section{TABLE 1: Electricity supply industry policy}

$$
\text { Policy }
$$

Main Highlights
White Paper on the Energy

Policy of the Republic of South

Africa (1998)
- Introduction of IPPs into the generation market.

- Market restructuring through a "managed reform process".

- Separation of Eskom's generation and transmission.
Electricity Pricing Policy of the South African Electricity Supply Industry (2004)
- "Multi-market model with a number of generation clusters, IPPs, and an independent Transmission Company and a Transmission Systems Operator".

- "The Bill provides for non-discriminatory access to the Minister Hendricks, Statement electricity networks. This is to ensure participation of IPPs, including renewable energy producers [...]. The introduction of on the Energy Regulation bill (2005) IPPs has been identified as an opportunity that is in line with that strategy within the electricity sector".

- Introduced competition in the generation sector, greater private sector participation, non-discriminatory access to the

Energy Security Master Plan Electricity $2007-2035$ transmission system.

- Definitive approach to implementing new generation capacity: "Any private participation will be via the IPP mechanism with a power purchase agreement with Eskom".

Source: White Paper on the Energy Policy of the Republic of South Africa (1998); Electricity Pricing Policy of the South African Electricity Supply Industry (2004); Minister Hendricks, Statement on the Energy Regulation bill (2005); Energy Security Master Plan - Electricity 20072025 (2007).

Despite the formulation of these policies, entry and competition in the electricity industry had not occurred at a sufficient rate. One of the main hindrances was the lack of regulatory uncertainty regarding exactly how competition would be introduced into the industry. This 
certainty was finally provided in 2007 in the Energy Security Master Plan - Electricity $2007-2025$ ("Master Plan"). The Master Plan proposed the use of power purchase agreements. Power purchase agreements meant that IPPs had certainty that Eskom would purchase their generated capacity and thus ensured a safeguard against the risk they were undertaking in their investment. This regulatory certainty occurred only nine years after the White Paper called for market reforms in the industry. Over this time, investments in generation facilities had stopped, while demand for electricity grew as more households were electrified (which were previously not supplied with electricity). Between 1992 and 2006, the net maximum capacity fluctuated but never increased substantially. On average, the net maximum capacity increased by $0.48 \%$ per year in the period 1992-2006. In contrast, the peak demand for electricity grew by an average of $3.19 \%$ per annum.

The brief description above highlights policymakers' thinking over time. Even though the active participation of IPPs was encouraged, the regulatory framework uncertainty regarding how the new generation capacity would enter the market, how this capacity would be procured and the amount of new capacity required effectively meant that there was no private sector generation. Together with the strong opposition by various stakeholders to private sector participation as well as Eskom lobbying against this, the reforms to the market (in terms of unbundling) were not implemented, and the intended competitive outcomes envisaged by the White Paper were not realised. However, over this period, South Africa's industrial and residential electricity prices were found to be some of the lowest in the world (Thopil \& Pouris, 2013:3) and up to 2007 Eskom was still seen as an efficient entity (Eberhard, 2005).

\subsection{Supply crisis in South Africa}

In January 2008, South Africa began experiencing rolling electricity blackouts. Initially, about $20 \%$ of the country's generating capacity was unavailable. The reserve margin, which is the difference between the maximum available generation capacity and peak demand, fell from $15 \%$ in 2001 to $7 \%$ in 2007 . A reserve margin of at least $20 \%$ is required to accommodate planned maintenance and unplanned breakdowns.

The possibility of shortages was expressed by experts up to 10 years prior to the 2008 crisis. In the White Paper (1998), it is stated that one of the challenges in the sector is that, by around 2007 , the demand for electricity is projected to exceed generation capacity and that due to the long lead times associated with expanding capacity, strategies should be in place in the medium term.

Electricity regulations published in the New Generation Capacity (2009) provided the muchneeded impetus, encouraging new generation capacity following the supply crisis of 2008. These regulations not only specified that a power purchase agreement was needed to facilitate the agreement between IPP generators and the buyer (i.e. Eskom in this case), but also provided for the development of an integrated resource plan ("IRP") (Pickering, 2011). The IRP regulates the licensing of new generation capacity as well as the cost recovery arising from capacity generated by IPPs. Thus, even from a policy perspective, the discussion on unbundling was limited. Instead, the relevant discussion centred on providing regulatory certainty regarding government's commitment to private sector participation in electricity generation.

Unbundling seemed to become a focus again in 2011 when the Independent Systems and Market Operator (ISMO) Bill of 2011 was promulgated. The ISMO Bill specified that the ISMO would be a state-owned company that would take on the tasks of both a systems and market operator. As 
systems operator, the entity is required to serve a technical purpose and operate or coordinate operation of the transmission system. As a market operator, it acts as a centralised institution that operates the organised market for the commercial exchange for energy (Steyn, 2012:547549). This would separate the generation and transmission functions of Eskom and ensure that generators would receive access to transmission resources on a fair basis.

\subsection{The Renewable Energy Independent Power Producer Procurement Programme ("REIPPPP”)}

In August 2011 the Department of Energy introduced a competitive bidding process for IPPs to supply electricity, referred to as the Renewable Energy Independent Power Producer Procurement Programme (REIPPPP). According to the Department of Energy (2012), the programme was implemented to achieve the 3725 megawatts required to ensure the continued uninterrupted supply of electricity. The process involves rounds of bidding for the supply of energy from various renewable sources. The successful bidders then enter into a PPA with Eskom. This ensures that there is certainty that all output generated by successful bidders will be purchased at the price indicated at the time of bidding. This certainty acts to mitigate risk for the IPPs.

There have been three bidding rounds where preferred bidders have totalled in excess of 2800 megawatts. A fourth round of bidding was expected to start in August 2014 (Eberhard, Kolker \& Leigland, 2014:1). The REIPPPP has been successful in offering a transparent and well-designed mechanism for IPP participation in the generation market which provided reasonable profitability. The support of government also played in role in reducing the perceived risk of investing in such a programme. This included the PPAs between IPPs and Eskom being underwritten by the National Treasury. This acts to reassure independent producers who may have considered entering into an agreement solely with Eskom as too much of a risk.

Via the competitive bidding process, successive bidding rounds saw the price of electricity from the various renewable sources decrease. This was achieved by creating competition through limiting the amount of electricity the producers could bid to supply. In some instances price caps were imposed on electricity generated from certain sources so as to prevent prices from being set too high. Competition was also intensified by allowing a large number of bidders in each round.

The process has been successful in encouraging competition in the generation market through a process that assures investors of transparency, profitability and mitigated risks. However, it is felt that for this procurement process to remain sustainable there is a requirement for a formal institution that has built-in institutional capability to ensure the continuation of the process such as an independent system and market operator (Eberhard et al., 2014:1). Also, the total capacity on offer, while in line with IRP 2010-2030, is possibly not enough to address current urgent shortages.

Thus even though projects to expand capacity are currently underway, and IPPs have increased their participation in the generation of electricity, supply is currently below the optimal or desired level. Although the success of the REIPPPP has shown that competition is possible (particularly in the generation section), that alone may not be sufficient to bring about an adequate level of entry and competition in the entire electricity industry. 
The question that remains then is whether the vertical separation of Eskom (as envisaged in the ISMO bill) in this context would bring about the desired level of competition and generate sufficient supply to resolve the market issues. The vertical separation of Eskom could bring about greater competition in generation in two ways. Firstly, should Eskom retain no control of the transmission network, there would be a guarantee of access to the transmission grid for independent producers on a fair and non-discriminatory basis. Secondly, if Eskom is not the most efficient firm in the generation market, vertical separation could encourage more entry in generation, as the purchase of electricity to be transmitted could be based on certain criteria such as the lowest price. In this case, a greater proportion of the electricity supplied could be on the basis of a competitive process similar to that observed in the REIPPPP.

\section{SOUTH AFRICA'S PIPED GAS SECTOR}

Two types of piped gas are used in South Africa: (i) natural piped gas sourced from Mozambique, and (ii) methane-rich gas produced by Sasol Gas Limited (Sasol Gas) in Secunda, Mpumalanga (REF). The use of piped gas in South Africa is relatively low compared to other middle-income countries. This is due to the fact that piped gas is thus far largely limited to industrial applications in South Africa (Melamu, 2011:1).

\subsection{Structure of the Piped Gas sector}

The functional market for piped gas is categorised as follows: transmission, distribution, reticulation or trading levels.

Transmission refers to the bulk transportation of gas by pipes supplied to a distributor, reticulator, and/or storage company, or any eligible customer.

Distribution refers to the distribution of bulk gas or transportation by pipelines with a general operating pressure of more than 2 bar gauge and less than 15 bar gauge.

Reticulation refers to the division of bulk gas supplied or transported by pipelines with a general operating pressure of no more than 2 bar gauge (Gas Act, 2001).

\subsection{Market structure concerns}

The gas market is highly concentrated, with Sasol Gas operating as virtually the only supplier and importer of gas in South Africa. Competition in this market is further limited at the distribution and reticulation levels of the value chain. Sasol Gas operates as a gas distributor in Gauteng, KwaZulu-Natal, North West and Mpumalanga. However, Sasol Gas also operates as a gas supplier for reticulators such as Spring Lights, NOVO Energy and Egoli Gas, which then resell this gas to their customers.

In the consent order agreement between the Competition Commission (the Commission) and Egoli Gas (Pty) Ltd (Egoli Gas), the Competition Tribunal (the Tribunal) noted that the Gas Act specifies that the distinguishing feature between a distributor and reticulators is the general operating pressure of pipelines. The difference between a gas distributor and a gas reticulator meant that, technically, Sasol Gas (as a distributor) can operate as a supplier and competitor with the downstream participants (reticulators) in the piped gas sector, as it can compete for 
the same set of customers serviced by gas reticulators. Further, this type of relationship may be construed to further impede downstream competition in the domestic piped gas sector.

Indeed, the vertical integration and concentrated nature of the piped gas sector has been noted to limit downstream competition in the domestic market (NERSA, 2012:19). The Commission found evidence of (a) market allocation and price-fixing arrangements with Spring Lights Gas (Pty) Ltd (Spring Lights) relating to piped gas in the Durban South area; and (b) marketallocation arrangements with Egoli Gas with regard to piped gas in the Johannesburg area.

In both cases, the respondents operate as reticulators of piped gas in the designated areas, with Sasol Gas as their exclusive supplier. However, both respondents entered into gas supply arrangements with Sasol Gas that restrained the respondents from supplying gas purchased from Sasol Gas to any customer other than the designated customers allocated to it and prevented them from supplying gas to customers for consumption outside the allocated supply areas. Both parties were found to have contravened section 4(1)(b) (ii) of the Competition Act (1998), which prohibits firms in a horizontal relationship from engaging in conduct that amounts to dividing markets by allocating customers, suppliers, territories, or specific types of goods or service.

Egoli Gas stated that the rationale for entering into such an agreement with Sasol Gas was due to the "flux in the regulatory framework for piped gas". Up until 2000, Egoli Gas was granted an exclusive licence to supply piped gas to customers within the municipal boundary of the Greater Johannesburg area, which excluded Roodepoort, Randburg and Sandton. This licence did not specify conditions on the operating pressure of the pipelines, as the Gas Act had not yet come into existence. The change in the regulatory regime following the Gas Act (2001) allowed Sasol Gas to obtain licences from NERSA to operate as a gas distributor and engage in gas-trading activities in various areas of Gauteng, Free State and Mpumalanga. Certain of the areas in which Sasol Gas was granted distribution and trading licences are located within the area of the exclusive licence granted to Egoli Gas. This meant that Sasol Gas and Egoli Gas were potential competitors in the geographic areas in which both had licences to operate as a distributor (in the case of Sasol Gas) or a reticulator (in the case of Egoli Gas). The threat of competition is even more real when you consider that as "an end customer it can be supplied equipment (at cost) that is used to reduce the pressure of the gas supplied from above 2 bar gauge to below 2 bar gauge and vice versa" (Competition Tribunal, case no: 016402; para 2.3). A similar situation ensued in the Durban South area between Sasol Gas and Spring Lights.

The most salient message learnt from the Egoli Gas and Spring Lights cases is that there clearly can be competitive rivalry between the vertically integrated supplier and its downstream competitors. In these circumstances, it can be thought that vertically separating Sasol Gas to allow for greater competition upstream may give rise to positive benefits to the competitive structure of this sector. This line of thought was expressed in the workshops held by NERSA with stakeholders in the piped gas sector, where several stakeholders opined that in order for competitors to be afforded an opportunity to access the pipeline, the pipeline operator should not operate as a gas trader in the same market (NERSA, 2012:19).

However, this line of thinking omits the fact that the gas industry in South Africa is still in its infancy. The fact that there are 67 production licence permits issued or under consideration for onshore exploration and production activities attests to the fact that the industry is in its early stages of development (PWC, 2012:30).

NERSA's assessment of the impact of the vertical nature of this industry concluded that in the context of a "nascent industry", market growth is dependent on (a) the exploration and 
importation of gas, and (b) the construction of infrastructure to support the industry. NERSA further stated that the vertical separation of this industry at this early stage may serve as an additional hurdle to the development of the industry (NERSA, 2012:20).

\subsection{Vertical separation and competition in the piped gas sector}

Even though the South African market is vertically integrated and competition concerns have arisen due to this, there are policy measures in place to further develop competition in the market. Kate et al. (2013:32) outline the necessary conditions which need to be in place for competition to develop in the market. The figure below provides an illustrated example of the envisaged approach.

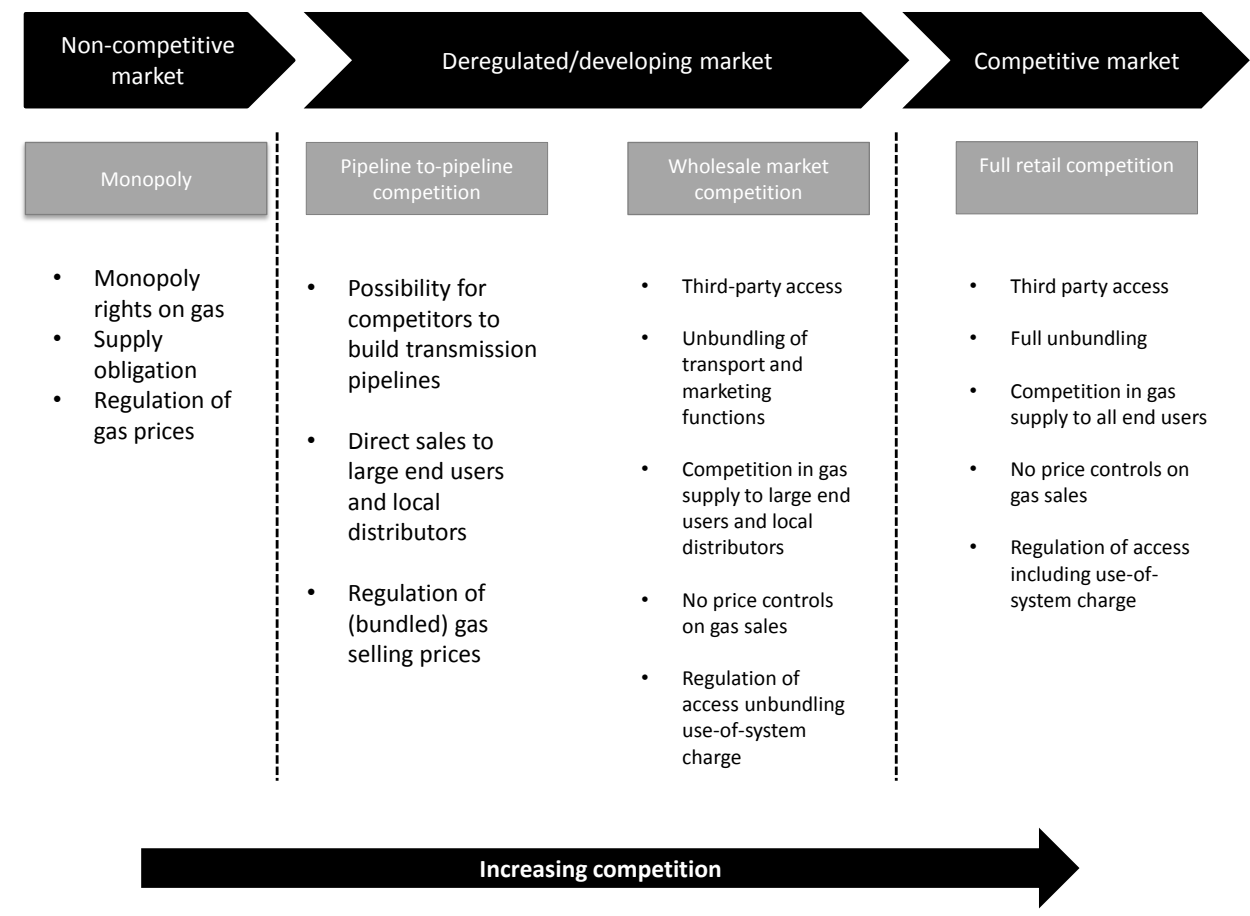

FIGURE 2: Framework to increase competition in the natural gas market

Source: Kate et al. (2013:33)

As displayed above, as part of a developing market, introducing pipeline-to-pipeline competition and wholesale market competition are the two necessary requirements in the development of a competitive market. Analysing the current legal framework in South Africa's piped gas sector shows that there are measures in place which satisfy the requirements above.

In terms of pipeline-to-pipeline competition, the possibility for competitors to build transmission pipelines may be limited, as the piped gas sector is firstly heavily dependent on foreign supply, while the demand for piped gas in the market is of such a nature that it is dependent on secured supply. Thus a circular problem occurs where in order for transmission competition to exist, suppliers have to make the necessary gas infrastructure investments. However, this infrastructure is not invested in when supply for piped gas is uncertain. Concerns revolving around supply uncertainty are the impeding factor to the required development of 
distribution and transmission infrastructure in South Africa (PWC, 2012). This is because once the infrastructure is in place, industrial, commercial and domestic users may be more willing to consider converting to gas-fired energy sources.

With regard to wholesale market competition, NERSA is mandated by the Gas Act (2001) to set the maximum prices for all classes of customers of piped gas. However, NERSA is required first to determine that there is "inadequate competition as contemplated in Chapters 2 and 3 of the Competition Act, 1998". Currently, NERSA sets the maximum price of gas on the basis of a basket of alternative fuels in South Africa. Tariff guidelines applicable to transmission, storage and reticulation of gas are also available (Mondliwa \& Roberts, 2014:35).

Thus there are features of the South African piped gas sector that when measured against the Kate et al. (2013) framework are indicative of a market progressing towards a competitive situation. Moreover, the existence of an energy regulator that effectively monitors and sets the rules for the market is further evidence of an environment that has actively created a foundation where competition may develop. It can be argued that once infrastructure is established, increased competitive rivalry could ensue. However, in order for infrastructure to be developed, adequate supply of piped gas is required. The piped gas sector is currently in its infancy. This then poses the question whether the vertical separation of the distribution and transmission functions from generation would facilitate competition in a market operating at this stage.

\section{UNBUNDLING AND ENTRY - THE INTERNATIONAL EXPERIENCE}

The international experience with unbundling as a factor facilitating competition in electricity and gas markets has yielded mixed results. Notably, the evidence from Europe suggests that in order for a wholesale market to be competitive, potential entrants into the generation level of a network industry require access to the transmission system. This is thought to be best achieved by ownership separation of the transmission level from generation activities.

However, the experience in California and Chile suggests that the mere separation of the transmission system from generation does not always lead to outcomes encouraging entry into the market. This indicates that for unbundling to facilitate entry and increase competition, other market conditions need to be met. The case studies used in this analysis highlight the fact that one should not consider unbundling as the panacea to foster competition in regulated network industries.

\subsection{Vertical separation as an 'entry facilitator'?}

The United Kingdom (UK) provides an example of the benefits and disadvantages of restructuring the electricity sector. The UK is divided into three distinct regions: England and Wales, Scotland and Northern Ireland. Each region implemented a different market reform process. England and Wales vertically separated the ownership of their generating companies from the transmission system. Northern Ireland adopted the Single Buyer Model, where the transmission and distribution company, Northern Ireland Electricity (NIE), held long-term power purchase agreements (PPAs) with the three generating companies operating in England and Wales. Scotland did not undergo any structural reforms to its electricity market. Instead, the two vertically integrated incumbents were privately owned. 
Cost-benefit analyses of these three different reform models have been conducted by Newbery and Pollit (1997) together with Pollit (1998). These analyses show that even though a wholesale electricity market was created in England and Wales, the gains of unbundling remained with the generating companies. This is because for the first five years after reforms there was little entry at the generation level, and consumers still continued to face high electricity prices. It was only after additional regulatory intervention, in the form of forced divestment of capacity, was imposed that the market concentration in the generation level decreased.

Consumers in Northern Ireland and Scotland faced higher electricity prices than those in England and Wales. The lack of competitive pressure meant that by 2000 prices in Scotland were approximately $5 \%$ higher than those in England and, notably, prices in Northern Ireland also remained high despite the use of long-term PPAs. Thus, Northern Ireland's use of long-term PPAs had limited impact on the market. It was only when unbundling was implemented together with additional regulatory measures that a competitive outcome arose (this outcome was indicated by the fall in market concentration and retail prices). This suggests that unbundling is a necessary step in the reform process, but is not sufficient on its own to guarantee that competition in a regulated network industry will arise.

The experience in the $\varepsilon U$ also indicates that the unbundling regime adopted is also important to consider when analysing the impact on market entry. The $\varepsilon C$ implemented three policy directives with various unbundling approaches that have had mixed results with facilitating entry (Eskenazi, 2012).

- The $\varepsilon C$ first introduced the 1996/92/CE Directive, which allowed for the accounting unbundling (i.e. accounts separation) of the generation and retail stages of the electricity sector. Third-party operators experienced access problems under this regime when the vertically integrated entities favoured the affiliated downstream firm by granting that firm preferential access to the transmission grid.

- The $2003 / 54 / C \varepsilon$ Directive promulgated the regulation of third-party access and established mandatory national regulatory bodies. This Directive replaced accounting unbundling with legal unbundling, where the generating companies would retain ownership of their transmission grid assets, but the transmission company would be legally independent of generation (with its own autonomous management and under strict regulatory control).

- The $\varepsilon C$ implemented the 2009/72/CE Directive following the findings of the $\varepsilon C$ Sector Inquiry into the electricity and gas sectors. The 2009/72/CE Directive broadened the previous sector legislation by proposing the 'effective separation of networks from activities of generation and supply'. Two ownership unbundling models were originally proposed by the $\varepsilon \mathrm{C}$ :

- Full ownership unbundling (FOU) - networks are not controlled or majority-owned by supply companies.

- Independent system operator (ISO) - the transmission network remains under the ownership of the supply companies, while the operation and control of the supply business is transferred to an independent systems operator.

The 2009/72/CE Directive was met with strong opposition led by Germany and France ( $\varepsilon C, 2008$ ). The opposing parties argued that increased competition was possible without implementing an ISO model, especially if sufficient safeguards were in place to monitor the independence, management and investment decisions of the supply companies (Massoni, 2003). The opposing parties argued against implementing the FOU model, stating that 'no correlation can be found 
between implementing ownership unbundling and the levels of prices and investment decisions which are determined by other factors' (Euractiv, 2008).

Numerous studies that analyse the impact of the FOU model as opposed to the ITO model have been conducted. Zachmann (2007) conducted an econometric comparison of the responsiveness of electricity prices to cost changes in the UK (FOU) and Germany (ITO). The study found that electricity prices in the UK were more responsive to short-run cost factors as opposed to those in Germany, suggesting that competition in the German electricity market may be limited. Further, the experience in France with the ITO model implemented in the gas and electricity sectors demonstrates the disadvantages of this form of unbundling. Both sectors remain relatively concentrated at the generation level, while the transmission capacity is limited ( $\varepsilon C$ French energy market review, 2011). On the other hand, Gugler et al. (2013) came to a negative conclusion concerning the dynamic effects of ownership unbundling on the transmission grid. In their cross-country study, they found that unbundling of generation from the grid stages reduces the aggregate investment rate in the sector by at least $10 \%$.

These examples demonstrate that introducing competition in the market through vertical separation of generation from other functions in the production chain is a complex and uncertain process, as numerous other market forces are also at play. Thus, given these uncertainties, deeming vertical separation to be the panacea for market reforms is a misjudgement.

\section{The pitfalls of vertical separation}

The California case is usually cited as an example of the risks associated with restructuring. California began its reforms in its electricity sector at a time when the market faced high production costs and high retail prices. The regulatory intervention implemented by authorities in the sector merely exacerbated the problems which existed in the industry. Following the vertical separation of the three investor-owned utilities (IOUs), average wholesale electricity prices remained three times higher than those of the previous year (Newbery, 2001:11), and rolling blackouts of electricity started together with stage 3 alerts (these alerts occur when reserve margins fall below $1.5 \%$. When this happens, disconnection is essential to protect system integrity). The implementation of price caps in response to this had little effect on the market apart from the IOUs exporting to neighbouring states, while the third-party generators stopped their supply to the domestic market (presumably, for fear of not being paid).

Several reasons for this outcome have been put forward by commentators (see Borenstein, 2001 and Newbery, 2001). These range from a poor market design that allowed for market manipulation when capacity was already constrained prior to restructuring, as well as the fact that distribution companies were dissuaded from signing long-term contracts for electricity (Newbery, 2001:12). The main lessons that can be drawn from California's experience with electricity reforms are:

- Capacity-constrained markets (where the reserve margin falls below 10\%) are likely to have volatile and high prices (Newbery, 2001:12). These high prices are likely to have little effect on demand (as electricity demand is largely unresponsive to price), but contribute to creating increasing and significant market power for the suppliers.

- Transitioning from a vertically integrated utility to a separated entity is said to introduce price risks between generators and suppliers. High wholesale prices provide generators with upstream profits that are matched by the losses of downstream suppliers, who have to buy 
at the high wholesale prices and sell at predetermined retail prices. This could be avoided with hedging contracts between generators and suppliers.

The California example highlights that applying a "cut and paste" approach to the restructuring of electricity markets without taking cognisance of the intrinsic factors impacting the functioning of the local market leads to an outcome that calls into question the conventional wisdom that unbundling is a prerequisite to facilitating entry.

Chile was among the first countries to reform its electricity market. By 1990, the electricity industry had undergone extensive privatisation and the generation, transmission and distribution services were partially unbundled (USITC, 2000:18-1). Under this legislation the transmission network was under regulation. Analysis by the Inter-American Development Bank (IADB) found that the inadequate regulation of the transmission network hampers competition in generation, as private sector generators will be unfairly dispatched on the transmission grid (IADB, 2006:75). At the time of the reforms, Chile's market structure consisted of two stateowned entities, Endesa and Chilectra (IADB, 2006:76). Endesa retained the ownership and operation of the main transmission system, which was managed by Transelec, a subsidiary of Endesa, while Chilectra's generation and distribution activities were horizontally and vertically separated (USITC, 2000:18-2).

This situation led to the National Economic Prosecutor filing a request with the Resolution Commission against Transelec, Chilectra, Endesa and Enersis to further unbundle the generation, transmission and distribution businesses (Beato \& Laffont, 2002:74). The prosecutor maintained that competition at the generation level would occur when the transmission system did not limit entry to or operating in the upstream generation level.

The companies gave several reasons why vertical separation was both unnecessary and unwarranted for the Chilean electricity sector. They argued that as the industry and its prices were regulated, there were sufficient safeguards in place to prevent an abuse of dominance. Further, they also argued that the arrival of natural gas from Argentina would allow for more power plants to be built and would effectively facilitate the entry of new players upstream (Beato \& Laffont, 2002:76-78). This would limit the importance of the current transmission network.

The Resolution Commission found that the prosecutor had not sufficiently proven that the companies charged had abused their market power. Even after its own investigation of the industry, the Resolution Commission did not find any evidence that the separation of companies in the sector was warranted. In fact, the Resolution Commission argued that the current ownership structure was not a significant factor in adversely affecting current or potential competition.

This example also shows that one needs to take note of the dynamic nature of the market, that entry may occur naturally through market developments (such as the importation of gas from another country) and that these market developments may also facilitate a competitive outcome.

\section{POLICY IMPLICATIONS FOR SOUTH AFRICA}

The examples above demonstrate mixed experiences with regard to the effects of unbundling as an 'entry facilitator' into the gas and electricity markets. The evidence from Europe and the 
United Kingdom suggests that in order for a wholesale market to be competitive, potential entrants require access to the transmission system. This is thought to be best achieved by ownership separation of transmission from generation.

However, the experience in California and Chile suggest that the mere separation of the transmission system from generation does not always lead to outcomes encouraging entry into the market. This suggests that for unbundling to facilitate increased competition and entry, other conditions must be met. Further, this indicates that the timing of reform steps is important when assessing the impact of unbundling on competition. In particular, when drawing lessons from these international experiences, it is important to bear in mind whether the unbundling of transmission systems occurred prior to privatisation or whether unbundling took place before the introduction of incentive regulation. Thus one cannot merely consider ownership unbundling as the panacea of competition matters in regulated energy industries. All examples used above suggest that appropriate regulation. (Note: our intention with the paper was to provide considerations for policy purposes, as such we were not focused on concluding on specific types of regulation that would be appropriate) of these markets is required. Without it, there are serious risks that the benefits of unbundling may be lost and hence the reform process may be undermined.

The international experience also shows that creating an environment that is conducive to completion is not solely determined by the market structure of the industry. Factors such as incentive regulation, regulatory certainty and the stage of development of the industry are important to consider as well.

A policy recommendation arising from this analysis is that the regulatory authorities in these industries must bear in mind the level of development of the industry in question. This is to ensure that restructuring should favour the natural evolution of the electricity and gas industries. Less strenuous reforms (such as legal unbundling) may be appropriate in the early development stages of the industry, and through a gradual process reforms will change as the industry changes.

This is particularly relevant for the South African piped gas industry, which is in its early stages of development. As growth in the industry is currently dependent on (i) exploration and (ii) construction of infrastructure to support the industry, vertical separation may require further infrastructure investment to be undertaken by individual market participants. Given the scale requirements of this industry, potential entrants may find that entry is either not financially viable or it may be that entry is viable only if consumers are to pay high prices. On this basis, it may be favourable for the current market structure to remain in place until the industry is developed enough for unbundling to take place and also be beneficial.

With regard to the electricity sector, ensuring regulatory certainty from government in terms of its commitment to private sector generation is one of the key issues which needs to be addressed. This is particularly important to consider prior to the start of the vertical unbundling process as envisaged by the ISMO Bill. As the sector is in a precarious position with regard its low generation capacity and unmet demand for electricity, increased generation capacity is required for the sector to function efficiently.

This means that increasing the incentive to invest in generation and transmission capacity should be a key requirement under the new dispensation. However, implementing an unbundling regime with the current capacity constraints in the market is likely to lead to perverse effects on market prices. Thus as a policy recommendation to consider in South Africa, the capacity constraints of the market 
should be addressed prior to implementing the unbundling regime stipulated in the ISMO Bill. The REIPPPP has illustrated that where regulatory certainty exists PPAs can be used as an effective tool to encourage entry and competition in the generation sector. This may be helpful in addressing the capacity issues outlined earlier. Perhaps the effective use of longer-term PPAs should be undertaken first, as this will allow for more private sector generators to enter the market.

However, it is important to note that other areas of the supply chain need to be well equipped to accommodate the increased generation capacity. It has been noted that in the case of the REIPPPP, transmission planning was not synchronised with the award of generation projects. This has created a fear that some of the awarded projects may not be able to connect to the grid as planned (Eberhard, Kolker \& Leigland, 2014:35). This further strengthens the case for having an ISO as one of the reforms to be used to achieve the desired outcome in the electricity industry.

Further, should unbundling as envisaged by the ISMO Bill take place, the following conditions (in line with those provided by Newbery (2001:7-8) for a successful transition should be considered:

- Potential suppliers must have fair and non-discriminatory access to the transmission system so that the wholesale market is competitive.

- Network infrastructure should be adequate and reliable, generation capacity should be adequate and there should be security of supply of primary fuels (such as coal in the case of South Africa).

- The markets of the liberalised utilities require appropriate regulation.

The first two conditions are repeatedly addressed in the policy and the literature; however, the third condition may be especially critical in the South African case. Even after unbundling, Eskom may possess market power at any level of the supply chain in which it competes. Thus 'the potentially competitive elements still need regulatory oversight to ensure that markets are not manipulated nor market power abused' (Newbery, 2001:8).

As transitioning from a vertically integrated utility to a separated entity is said to introduce price risks between generators and suppliers, hedging contracts between the two parties should be introduced to mitigate against this (Newbery, 2001:13). The use of hedging contracts will help to insure against any perverse effects the unbundling process will have on electricity prices. As the ISMO Bill currently stands, no protective measure against this price effect is stipulated. Therefore a policy recommendation would be to include measures in the policy framework which would ensure that consumers are protected against these price risks.

It also important that the type of vertical separation as envisaged by the ISMO Bill is carefully considered and clearly articulated. As seen in the case of the 2003/54/CE Directive, a "softer" form of separation like accounts separation still left access to the transmission grid under the control of an entity that also competed in the downstream market through an affiliated firm. This created incentives to discriminate against other downstream firms by providing the affiliated downstream firm with preferential access to the transmission grid. Thus, in this case it would be critical to clearly define the extent of the control Eskom would have (if any), especially of the transmission grid, should the vertical separation of Eskom occur.

As illustrated by the international experience, this paper shows that unbundling is just one step in the reform process. On its own, it is unlikely to have a significant effect on entry. However, unbundling together with appropriate incentive regulatory measures and the use of efficient long-term PPAs are tools which are required to further facilitate entry into regulated network industries. This paper has also highlighted that unbundling should be approached with caution. 
The experience in more established markets in the world is testament to this. As South Africa is in the process of establishing an unbundling regime, the lessons learnt in other jurisdictions should be borne in mind by policymakers. Instead of applying a "cut and paste" approach to unbundling, local conditions and factors which affect the market should be taken into account.

\section{LIST OF REFERENCES}

Beato, P. \& Laffont, J. (2002). Competition Policy in regulated industries: approaches for emerging economies. [Online] Available: http://idbdocs.iadb.org/wsdocs/. (Accessed 11 February 2014).

Borenstein, S. (2001). The trouble with electricity markets and California's electricity restructuring disaster. [Online] Available: http://www.hks.harvard.edu/m-rcbg/Events/Papers/RPP_5-202_Borenstein.pdf. (Accessed 8 March 2014).

Creamer Media (2008). SA terminates A\&S peaking-power contract. Engineering News, 3 April. [Online] Available: http://www.engineeringnews.co.za/article/sa-terminates-aes-peakingpowercontract-2008-04-03. (Accessed 10 March 2014).

Department of Energy (DoE), (2012), Renewable energy independent power producer procurement programme. [Online] Available: http://www.ipprenewables.co.za/. (Accessed 12 September 2014).

Department of Minerals and Energy (DME). (1998). White paper on the energy policy of the Republic of South Africa.

Department of Minerals and Energy (DME). (2004). Electricity pricing policy of the South African electricity supply industry.

Department of Minerals and Energy (DME). (2007). Energy security master plan-electricity.

Department of Energy (DME). (2009). Electricity Regulation Act, 2006, electricity regulations on new generation capacity.

Eberhard, A. (2005). From State to Market and Back Again: South Africa's Power Sector Reform. Economic and Political Weekly, December 10.

Eberhard, A., Kolker, J. \& Leigland, J. (2014). South Africa's Renewable Energy IPP Procurement Program: Success Factors and Lessons. World Bank Group.

Electricity Regulation Act No. 4 of 2006. (2006).

Eskom. (2001). Briefing to standing parliamentary committee on minerals \& energy. Eskom strategic intent and restructuring.

Eskenazi, L. (2012). Investing in the energy sector: between regulation and competition, the $\varepsilon U$ perspective. [Online] Available: http://boyanov.com/BNV_resources/uploads/2012/06/. (Accessed 11 March 2014).

Euractiv. (2008). Eight EU states oppose unbundling, table 'third way'. [Online] Available: http://www.euractiv.com/energy/eu-states-oppose-unbundling-tabl-news-219274. (Accessed 11 March 2014).

European Federation of Energy Traders (2000). Unbundling as a crucial factor in the completion of European electricity and gas market liberalisation. [Online] Available: http://www.efet.org/.

(Accessed 24 February 2014). 
Garcia, A. (2002). Colombia's natural gas industry: A competition failure. Competition Policy in Regulated Industries: Approaches for Emerging Economies. [Online] Available: http://wwwl0.iadb.org/intal/intalcdi/PE/2010/07297.pdf. (Accessed February 2014).

Gugler, K., Peev, દ. \& Segalla, દ. (2013). The internal workings of internal capital markets: Crosscountry evidence. Journal of Corporate Finance, 20, pp. 59-73.

Haucap, J. (2007). The costs and benefits of ownership unbundling. [Online] Available: http://www.econstor.eu/bitstream/10419/41967/1/555590658.pdf?origin=publication_detail. (Accessed 24 February 2014).

Hertzmark, D. (2012). Electricity at the right price. Proceedings of the Pacific Energy Summit. [Online] Available: www.nbr.org. (Accessed 8 March 2014).

Inter-American Development Bank (2006). Profiles of power sector reform in selected Latin American and Caribbean countries. [Online] Available: http://www.iadb.org/en/topics/topics-in-latinamerica-and-the-caribbean,1125.html. (Accessed 24 February 2014).

Kate, W., Varro, L. \& Corbeau, A. (2013). Developing a natural gas trading hub in Asia: obstacles and opportunities. [Online] Available:

http://www.iea.org/media/freepublications/AsianGasHub_WEB.pdf. (Accessed 8 March 2014).

Le Roux, M. (2008). Private electricity contract cancelled. Business Day, 3 April. [Online] Available: http://allafrica.com/stories/200804030237.html. (Accessed 9 March 2014).

Mali, T. (2013). Energy in South Africa. [Online] Available:

http://www.ic.daad.de/johannesburg/document/2013/UKZN\%20\%20Mali\%20South\%20Afican\%20Re newable\%20Energy\%20Developments\%20vl.pdf. (Accessed 5 March 2014).

Massoni, M. (2003). French electricity liberalization and the European context. [Online] Available: http://www.hks.harvard.edu/hepg/Papers/Massoni_french.elec.liberalization_5-10-03.pdf. (Accessed 11 March 2014).

Melamu, P. (2011) South African residential and commercial gas: unfolding scenarios. [0nline] Available: http://www.deloitte.com/assets/Dcom-

SouthAfrica/Local\%20Assets/Documents/South\%20African\%20Residential\%20and\%20Commercial\% 20Gas.pdf. (Accessed 7 March 2014).

Michaels, R.J., (2004). Vertical integration and restructuring of the U.S. electricity industry. [Online] Available:

http://business.fullerton.edu/economics/rmichaels/workingPapers/040921\%20Vl\%20complete.pdf. (Accessed 14 September 2014).

National Treasury (2013) Budget Speech Review: 2013. Pretoria, National Treasury.

National Energy Regulator of South Africa. (2008). Enquiry into the National Electricity Supply Shortage and Load Shedding. Pretoria: NERSA.

National Energy Regulator of South Africa. (2011). Determination of the Inadequate Competition in the Piped Gas Industry. Pretoria: NERSA.

National Energy Regulator of South Africa. (2012). Report on the NERSA dialogue on gas infrastructure investment. Pretoria: NERSA.

Newbery, D.M. (2001). Regulating electricity to ensure efficient competition. [0nline] Available: http://www.econ.cam.ac.uk/people/emeritus/dmgn/files/CEPR1101.PDF. (Accessed 8 March 2014). 
Pickering, M. (2011). The Winding Road of Energy Policy. In Baker, L. (eds.) Sustainable Energy Solutions for South Africa: Ensuring Public Participation and Improved Accountability in Policy Processes (pp. 5).

PricewaterhouseCoopers. (2012). An analysis of the potential of the natural gas industry in South Africa. [Online] Available: http://www.pwc.co.za/en/publications/the-gas-equation.jhtml. (Accessed 14 September 2014)

Pollitt, M. (1997). The restructuring and privatisation of the electricity supply industry in Northern Ireland: will it be worth it? University of Cambridge, Department of Applied Economics. (Working Papers Amalgamated Series no. 9701).

Polo, M. \& Scarpa, C. (2002). The liberalization of energy markets in Europe and Italy. Proceedings of the Conference "Monitoring Italy", 10 January, Rome.

Soares, I. \& Sarmento, P. (2010). Does unbundling really matter? The telecommunications and electricity cases. [Online] Available: http://wps.fep.up.pt/wps/wp380.pdf. (Accessed 15 February 2014).

Steyn, G. (2003). Administered prices: Electricity. National Treasury, Pretoria.

Steyn, $\varepsilon$. (2012). Dawn of a competitive electricity sector in South Africa: The independent system and market operator Bill B 9-2012 - context, content and comment. De Jure, 46(2), pp. 539-556.

Thopil, G.A. \& Pouris, A. (2013). International positioning of South African electricity prices and commodity differentiated pricing. Electricity Pricing in South Africa.

The European Parliament and the Council of the European Union. (1996). Directive 96/92/EC of the European parliament and of the council of 19 December 1996 concerning common market rules for the internal market in electricity.

The European Parliament and the Council of the European Union. (2003). Directive 2003/54/EC of the European parliament and of the council.

The European Parliament and the Council of the European Union. (2009). Directive 2009/72/EC of the European parliament and of the council of $13 \mathrm{July} 2009$ concerning rules for the internal market in electricity and repealing Directive 2003/54/C.

The Gas Act No. 48 of 2001.

United States International Trade Commission. (2000). Electric power services; recent reforms in selected foreign markets. [Online] Available:

http://www.usitc.gov/publications/docs/pubs/332/pub3370.pdf. (Accessed 23 February 2014).

Zachmann, G. (2007). A Markov switching model of the merit order to compare British and German price formations. DIW Berlin, German Institute for Economic Research. 
Sithebe \& Kolobe 